\title{
A multiple biomarker approach to tracking the fate of an ice algal bloom to the sea floor
}

\author{
Nathalie Morata $\cdot$ Michel Poulin $\cdot$ Paul E. Renaud
}

Received: 22 November 2009 / Revised: 15 June 2010 / Accepted: 7 July 2010 / Published online: 24 July 2010

(C) The Author(s) 2010. This article is published with open access at Springerlink.com

\begin{abstract}
In ice-covered Arctic seas, the ice algal production can be the main input of organic matter to the ecosystem. Pelagic-benthic coupling is thought to be particularly tight in those areas. The increase in ice algal production in Franklin Bay from January/February to April/May 2004 paralleled an increase in benthic oxygen demand. However, sedimentary chlorophyll $a$, which is usually an indicator of "fresh" organic matter inputs to the sea floor, did not increase. Consequently, it was asked what was the fate of the ice algal phytodetritus arriving at the sea floor? To answer this question, photosynthetic pigments from the sea ice, water column particulate organic matter, and sediment, as well as diatom frustules in the sediment, were studied from January to May 2004. The number of ice diatom cells in the sediment showed an increase in April/May, confirming higher inputs of fresh ice algae to the sediment. Changes in sedimentary pigment profiles in the first $10 \mathrm{~cm}$ suggested an increase in bioturbation due to enhanced benthic activities. Finally, the decrease in the ratio of
\end{abstract}

N. Morata $\cdot$ P. E. Renaud

Department of Marine Sciences, University of Connecticut,

1080 Shennecossett Road, Groton, CT 06340, USA

Present Address:

N. Morata $(\bowtie)$

Department of Arctic and Marine Biology,

University of Troms $\varnothing, 9037$ Troms $\varnothing$, Norway

e-mail: nathalie.morata@gmail.com

M. Poulin

Research Division, Canadian Museum of Nature,

PO Box 3443, Station D, Ottawa, ON K1P 6P4, Canada

P. E. Renaud

Akvaplan-niva, Polar Environmental Centre,

9296 Troms $\varnothing$, Norway chlorophyll $a$ to phaeophorbide $a$ implied an increase in macrobenthic activity. Benthic macrofauna consumed some of the deposited material and mixed some within the top five $\mathrm{cm}$ of sediment. The response of sedimentary pigments to an ice algal input can be studied at different levels and it is only the combination of these studies that will allow an understanding of the overall fate of phytodetritus in the benthic compartment.

Keywords Arctic $\cdot$ Beaufort Sea $\cdot$ Diatoms $\cdot$ Sedimentary pigment $\cdot$ Pelagic-benthic coupling $\cdot$ Carbon cycle

\section{Introduction}

Marine primary production in the Arctic is primarily due to phytoplankton in the water column and microalgae associated with ice (Sakshaug 2004). Ice algae are generally found in the bottom layers of the ice sheet, in contact with the underlying sea water (Michel et al. 1996; Arrigo 2003; Lizotte 2003), and are represented by diatoms in Arctic and Antarctic seas (Günther and Dieckmann 1999; von Quillfeldt et al. 2003; Różańska et al. 2009). Ice algal production increases during spring due to the seasonal increase in irradiance (Wassmann et al. 2006). Although primary production rates by ice algae are generally low compared to phytoplankton, they contribute up to $57 \%$ of the total productivity in the central Arctic basin (Gosselin et al. 1997) and between 3 and 25\% on Arctic shelves (Legendre et al. 1992). Ice algae can be the main source of carbon for the pelagic food web (Gosselin et al. 1997; Nozais et al. 2001; Arrigo 2003); however, variations in the extent of the seaice cover indirectly impact the inputs of organic matter to both pelagic and benthic food webs by influencing the ice algal production. 
Grazing by ice fauna has been found to inefficiently control ice algal biomass (Werner 2000; Michel et al. 2002), and herbivorous zooplankton grazers are usually scarce in the spring. Thus, Carroll and Carroll (2003) suggested a mismatch scenario in ice-covered seas, resulting in strong vertical fluxes of undegraded particulate organic matter (POM) from the sea ice to the benthos. Moreover, recent studies have indicated that benthic organisms can derive energy directly from ice algae (Hobson et al. 1995; McMahon et al. 2006).

Sedimentary pigments have been used in short- and longterm studies assessing marine ecosystem change. Sedimentary chlorophyll $a(\operatorname{chl} a)$ is a marker of the "freshness" of the algal material flux reaching the sediment (Boon and Duineveld 1996). The presence of pigment degradation products in the sediments indicates the algal physiological status and the nature of processing that the chlorophyll pigment has undergone (Mantoura and Llewellyn 1983; Villanueva and Hastings 2000). Accessory pigments, which are light-absorbing compounds working in conjunction with chl $a$, are often specific for different algal groups and can be used as taxonomic markers (Gieskes and Kraay 1984; Jeffrey and Mantoura 1997). However, ice algae and phytoplankton diatoms have the same pigment signature, which means they can only be distinguished by a microscopic analysis of their respective communities. The direct study of diatom frustules in the sediment of Arctic shelves has revealed the presence of ice-associated diatom species under seasonally ice-covered waters (Sancetta 1981; Cremer 1999; Djinoridze et al. 1999; Polyakova 2003; Ambrose et al. 2005).

Previous studies in the Arctic have noted a positive correlation between sedimentary pigments and overlying production (Pfannkuche and Thiel 1987; Grant et al. 2002; Bessière et al. 2007). Since primary production varies greatly throughout the year, it has been hypothesized that inputs of organic matter to the sea floor also vary season- ally, in particular during the spring. When fresh organic matter reaches the sea floor, it can be stored as benthic biomass, respired, or buried.

The evolution of pelagic-benthic coupling in Franklin Bay in southeastern Beaufort Sea (Fig. 1) was followed from January to May 2004 during the Canadian Arctic Shelf Exchange Study (CASES) overwintering program. Ice algal biomass and downward fluxes of particulate organic material increased from the winter to the spring season (Riedel et al. 2006; Różańska et al. 2009). Sediment oxygen demand (SOD), a measure of labile carbon processed by the benthic community, also increased in April, as a response to an increase in ice algal phytodetritus inputs (Renaud et al. 2007). Unexpectedly, no increase in sedimentary chl $a$ was observed, leading to the question of whether an input of ice algal phytodetritus to the sea floor always leads to an increase in sedimentary pigments.

The main objective of this study was to understand the complex fate of ice algal inputs to the sea floor. Three possible non-exclusive responses can be foreseen. (H1) The inputs of fresh ice algal phytodetritus to the sea floor increases ice algae in sediment and change surface sediment biomarkers. (H2) The increase in food inputs to the sediment stimulates the benthos, which consumes it quickly, resulting in an increase in benthic activity, bioturbation, and pigment degradation products. (H3) Finally, some groups of organisms are stimulated by fresh inputs more than others (macrofauna vs. bacteria).

\section{Methods}

Study area

Sampling was conducted six times from January to June 2004 at a field station on first-year landfast ice in Franklin
Fig. 1 Canadian Beaufort Sea showing the position of the overwintering station in Franklin Bay (indicated by a star)

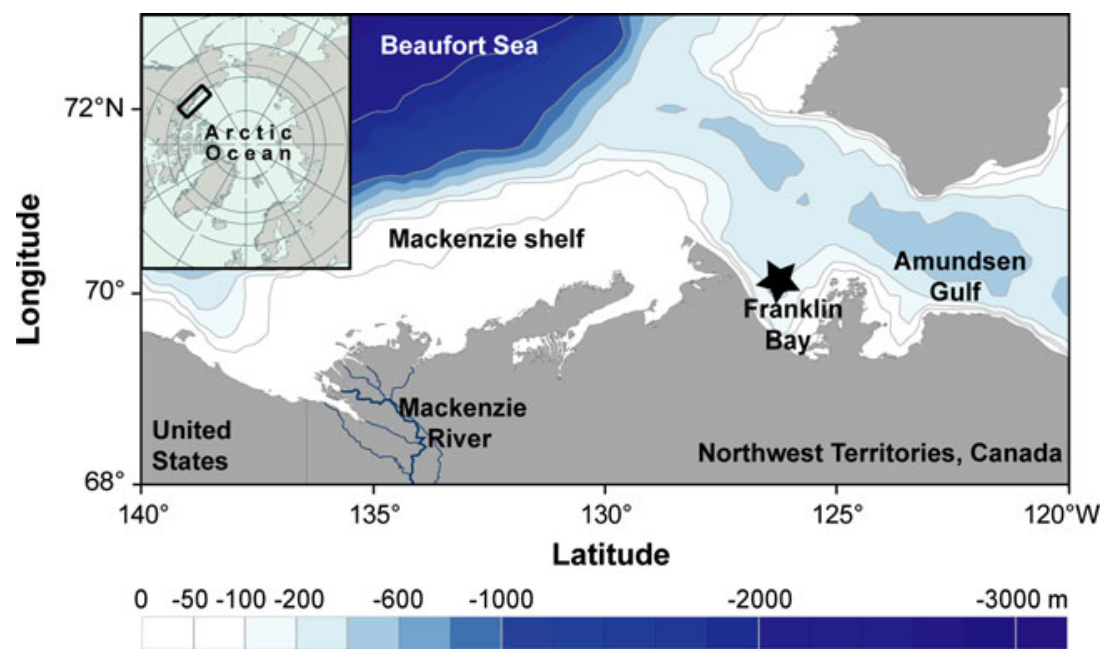


Bay $\left(70^{\circ} 04^{\prime} \mathrm{N}, 126^{\circ} 26^{\prime} \mathrm{W}\right.$; water depth ca. $\left.250 \mathrm{~m}\right)$, southeastern Beaufort Sea, Northwest Territories, Canada (Fig. 1). The station was $1.5 \mathrm{~km}$ northeast of the overwintering site of the research icebreaker CCGS Amundsen. Ice thickness increased from $1.3 \mathrm{~m}$ in February to a maximum of ca. $2 \mathrm{~m}$ at the end of May.

Ice and water column sampling

Ice samples were collected three times in January/February and three times in April/May. Three ice cores per sampling date were collected manually with a Mark II ice corer $(9 \mathrm{~cm}$ internal diameter; Kovacs Enterprises). The bottom $4-10 \mathrm{~cm}$ of each ice core was cut off and melted together in $1-5 \mathrm{~L}$ of $0.2-\mu \mathrm{m}$-filtered surface sea water to minimize osmotic stress (Garrison and Buck 1986). Four to $10 \mathrm{~L}$ of water $(15 \mathrm{~m})$ was collected on the same dates as for ice sampling in triplicates by a rosette through the ship's moon pool. Melted ice core and water samples were filtered onto Whatman GF/F filters, which were frozen at $-20^{\circ} \mathrm{C}$ prior to pigment analysis by high-pressure liquid chromatography (HPLC).

\section{Sediment sampling}

Sediment was sampled on four occasions (13 January, 11 February, 27 April, 7 May) from a box corer $(45 \mathrm{~cm} \times$ $45 \mathrm{~cm}$ ) and one more time on 6 April, from a piston corer. Due to difficulties in sampling logistics, the coring instrument was deployed only once at each sampling date. Three sub-cores $(5 \mathrm{~cm}$ diameter $\times 10 \mathrm{~cm}$ deep) were taken from the same box corer for sedimentary pigment. For all sampling dates, no fluff layer was observed, but the sedimentwater interface appeared to be intact, even when sampled with the piston corer. The cores were extruded and sliced at $1-\mathrm{cm}$ intervals under reduced light conditions. Each interval was divided in two, half for pigment analysis by fluorometry and half for pigment analysis by HPLC, although HPLC analysis was only performed on the top 2 surface layers. Both subsamples were wrapped in aluminum foil and frozen at $-20^{\circ} \mathrm{C}$ directly after slicing in order to avoid pigment degradation. Subsamples for the two first $\mathrm{cm}$ for stable isotope and diatom frustule analyses were taken with a truncated syringe $(1.4 \mathrm{~cm}$ diameter $)$. Samples for stable isotope analysis were directly frozen at $-20^{\circ} \mathrm{C}$. Samples for diatom frustule analysis were stored in a scintillation vial and preserved with $20 \mathrm{~mL}$ of buffered $3.7 \%$ formaldehyde.

\section{Fluorometric analysis}

Within 2 weeks, sediment subsamples were analyzed by fluorometry. Subsamples were placed in $60-\mathrm{mL}$ centrifuge tubes and $20 \mathrm{~mL}$ of $100 \%$ acetone was added. Tubes were stored at $-20^{\circ} \mathrm{C}$ in the dark for $48 \mathrm{~h}$ and shaken periodically. Prior to fluorometric analyses, the tubes were centrifuged at $4,000 \mathrm{rpm}$ for $10 \mathrm{~min}$ at $0^{\circ} \mathrm{C}$. The supernatant was analyzed in a Turner Designs Model 10-AU fluorometer before and after acidification with $5 \% \mathrm{HCl}$ in order to determine chl $a$ and phaeopigments (phaeo), respectively. Phaeo correspond to the total of chl $a$ degradation products and include phaeophorbide $a$ and phaeophytin $a$. Pigment concentrations were calculated according to Holm-Hansen et al. (1965).

\section{HPLC analysis}

Ice algae, POM and sediment samples were extracted and analyzed for pigment composition as described in Morata et al. (2008). In summary, ice algae and POM samples were extracted in $2 \mathrm{~mL}$ of 100\% HPLC-grade acetone for $12-24 \mathrm{~h}$, while $1-3 \mathrm{~g}$ of freeze-dried sediment was extracted in $8 \mathrm{~mL}$ of 80:20 HPLC-grade acetone:methanol. Five milliliters of the sediment extracts were reconcentrated by blowing to dryness under nitrogen and redissolving in $250 \mu \mathrm{L}$ of $90 \%$ acetone. Two hundred microliters of each sample were injected through a guard column to a reverse-phase Alltech Absorbsphere C18 column $(5 \mu \mathrm{m}$ particle size; $250 \times 4.6 \mathrm{~nm}$ id), using the program of Chen et al. (2001). Carotenoids were identified and quantified on the photodiode array (PDA) detector at $438 \mathrm{~nm}$, while chlorophylls and phaeopigments were quantified on the fluorometer detector. The quantification of each pigment was determined using response factor (RF) of pigment standard (DHI Water and Environment, Denmark). Chl $a$ is a marker of living algal cells while its degradation products, phaeophorbide $a$ and phaeophytin $a$, are usually related to grazing and various processes, including microbial degradation, respectively (Leavitt 1993). The accessory pigment used as a marker for diatoms is fucoxanthin. In addition, fucoxanthin allomeres, considered as degraded fucoxanthin, were identified (similar spectrum, but different retention time) and quantified using the response factor of fucoxanthin.

\section{Carbon and nitrogen stable isotope analysis}

Frozen sediment subsamples for stable isotope analysis were dried at $60^{\circ} \mathrm{C}$ overnight. To decalcify subsamples for carbon analysis, about $2 \mathrm{~g}$ of dry, homogenized sediment was placed in a crucible, where $2 \mathrm{~mL}$ of $1 \mathrm{~N} \mathrm{HCl}$ was added and then dried at $80^{\circ} \mathrm{C}$ overnight. This operation was repeated three times or until the sediment did not show a clear bubbling due to the conversion of carbonate to carbon dioxide gas. Decalcified sediment subsamples were used for $\% \mathrm{C}$ (organic carbon) and $\delta^{13} \mathrm{C}$ determination, while non-decalcified subsamples were used for $\% \mathrm{~N}$ and $\delta^{15} \mathrm{~N}$ 
analysis. Stable isotope analysis of sediments was performed by the Environmental Geochemistry Laboratory, Department of Geology, Bates College, Lewiston, Maine, using a ThermoFinnigan Delta V coupled to a Costech EA Conflo III combustion interface. All stable carbon isotope values are reported in delta $(\delta)$ notation, in units of per mille $(\% o)$, where $\delta=[($ Rsample/Rstandard $)-1] \times 1,000$. $R={ }^{13} \mathrm{C} /{ }^{12} \mathrm{C}$ and ${ }^{15} \mathrm{~N} /{ }^{14} \mathrm{~N}$, and the standards are Vienna Peedee belemnite (VPDB) and air for carbon and nitrogen, respectively. The reproducibility on the bulk sediment was $\pm 0.2 \%$, as determined by the standard deviation of multiple analyses.

\section{Diatom frustule analysis}

Diatom frustules were extracted from the sediment using Ludox/Colloidal Silica (L. Cooper, personal communication). Ludox has been previously used to separate algal material and microphytobenthos from detritus and sediment (Blanchard et al. 1988; Hamilton et al. 2005). Here, the centrifugation of sediment, Ludox, and distilled water creates a density gradient, allowing diatoms to aggregate in a layer at the interface between the Ludox-sediment and water layers. The $3.07 \mathrm{~cm}^{3}$ of sediment sample was placed in a $15-\mathrm{mL}$ polypropylene centrifuge tube. Sediment was rinsed with water, centrifuged at 2,200 rpm for $8 \mathrm{~min}$, and the supernatant was removed. This procedure was repeated four times. In order to have a 3-1 Ludox to sediment ratio, $9 \mathrm{~mL}$ of Ludox was added to the tube, which was then gently inverted a few times. Distilled water $(2.5 \mathrm{~mL})$ was placed on top of the Ludox-sediment mixture, and the tube was centrifuged 5-7 min at 1,800 rpm. The thin milky-like layer of diatoms was transferred to a new tube. In order to rinse the remaining Ludox, $10 \mathrm{~mL}$ of distilled water was added to the tube and centrifuged for $8 \mathrm{~min}$ at 2,200 rpm. The supernatant was removed, and the procedure was repeated four times. Diatoms present in the extract were counted using the method of Hamilton et al. (2002). When the cytoplasm remained in the cells, diatoms were counted as potentially viable cells. When more than half of the cytoplasm was missing, the cells were counted as empty.

\section{Results}

Ice algae and water column pigments

Increases in pigment concentrations were observed at the bottom of the sea ice and in the water column POM at $15 \mathrm{~m}$ from winter to spring (Fig. 2a-d). Chl $a$ concentration and chl $a$ :phaeo ratio increased for both ice and POM from January/February to April/May. This trend was similar for accessory pigments. Fucoxanthin concentration and fucoxanthin:degraded fucoxanthin ratio increased in April.

Surface sedimentary pigments and stable isotopes

Although chl $a$ and fucoxanthin concentrations increased in the bottom ice and POM in April, there was no similar increase in pigments in the top $2 \mathrm{~cm}$ of sediment (Fig. 2e, f). $\mathrm{Chl} a$ concentrations seemed to even decrease during the sampling period although the chl $a$ :phaeo ratio increased continuously and the fucoxanthin:degraded fucoxanthin ratio started to increase in May. Relative concentrations of degradation products of chl $a$ changed during the year: the chl $a$ :phaeophorbide $a$ ratio showed a decrease in April, while the chl a:phaeophytin $a$ ratio tended to increase (Fig. 3a). In order to compare pigment degradation products with benthic activities, the ratio of total community SOD to bacteria/meiofaunal oxygen demand ("minivial" SOD) was calculated from Renaud et al. (2007). While the total SOD increased by an order of magnitude from January/February to April/May, the minivial SOD only varied by a factor of two (Fig. 3a in Renaud et al. 2007). The overall ratio of the total SOD:minivial SOD increased through time (Fig. 3b). Stable isotopes and $\% \mathrm{~N}$ and $\% \mathrm{C}$ in surface sediment did not change from January to April (Fig. 4a, b). Since the \%C ranged from 1.28 to $1.33 \%$ dry weight sediment, the carbon from chl $a$ represented only $1-2 \%$ of the total sedimentary organic carbon.

Sedimentary pigment profiles

Vertical profiles of chl $a$ concentration in the sediment showed a sub-surface maximum in January/February (Fig. 5a, b) which disappeared in April/May (Fig. 5c-e). Chl $a$ concentration in the first $1 \mathrm{~cm}$ decreased from $0.13 \mu \mathrm{g} \mathrm{cm}^{-3}$ on 14 January to $0.05 \mu \mathrm{g} \mathrm{cm}^{-3}$ on 27 April. However, when averaging over the first $5 \mathrm{~cm}$ and $10 \mathrm{~cm}$, chl $a$ concentrations remained relatively stable throughout the sampling period (Fig. 6a). Finally, the chl $a$ :phaeo ratio, an indicator of the freshness of organic matter, generally increased with time, especially in the top $5 \mathrm{~cm}$ and was always higher when averaged over the entire section $(0-10 \mathrm{~cm})$ than in the top first centimeter (Fig. 6b).

\section{Diatom frustules}

The abundance of both empty and viable pennate diatoms showed an increase of $170-300 \%$ over the sampling period (Fig. 7). Most of the pennate diatoms identified at the species level (98-100\%) were represented by sea-ice algae (Table 1), and the three dominant taxa were Fragilariopsis cylindrus, Navicula spp. and Nitzschia frigida. 

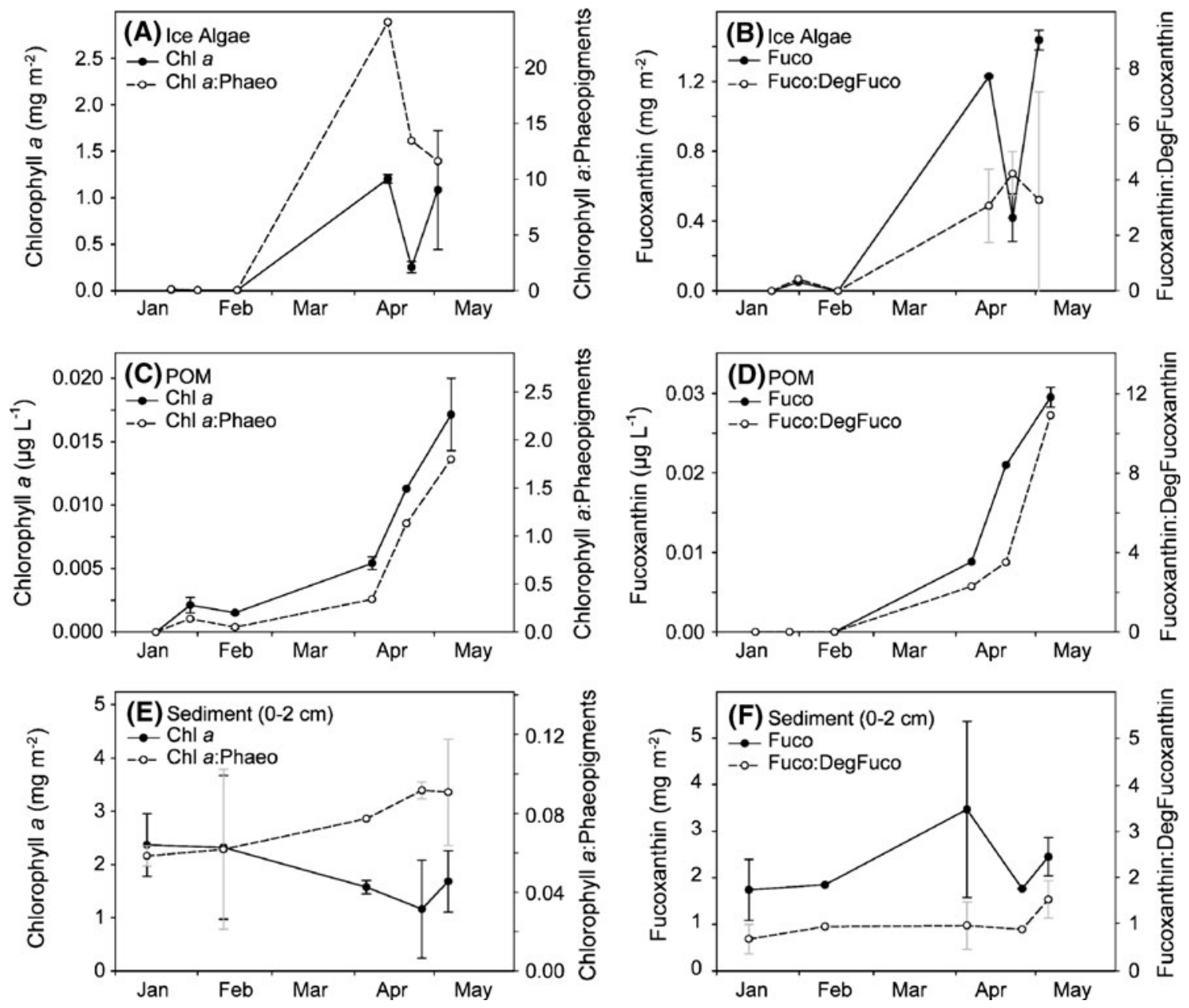

Fig. 2 Temporal variations of $(\mathbf{a}, \mathbf{c}, \mathbf{e})$ chlorophyll $a(\mathrm{chl} a)$ concentration and ratio of chl $a$ to phaeopigment (phaeo), and $(\mathbf{b}, \mathbf{d}, \mathbf{f})$ fucoxanthin (Fuco) concentration and ratio of fuco to degraded fucoxanthin

(DegFuco) in (a, b) the bottom ice, $(\mathbf{c}, \mathbf{d})$ water column particulate organic matter at $15 \mathrm{~m}$ and $(\mathbf{e}, \mathbf{f})$ top $2 \mathrm{~cm}$ of surface sediment in Franklin Bay from January to May 2004. Mean values \pm SD are shown

\section{Discussion}

The present study confirms that inputs of ice algae to the sediment increased from January/February to April/May and are a source of organic matter to the benthos, as suggested by Renaud et al. (2007). The following discussion in organized as an evaluation of the three hypotheses.

H1: Inputs of fresh ice algal phytodetritus to the sea floor increase ice algae in sediment and change surface sediment biomarkers

Previous studies on Arctic ecosystems have suggested local autochthonous primary production as a major factor determining sedimentary chl $a$ (Pfannkuche and Thiel 1987; Boetius and Damm 1998; Grant et al. 2002; Schewe and Soltwedel 2003; Clough et al. 2005; Bessière et al. 2007). In the Bering and Chukchi seas, increases in sedimentary chl $a$ have been reported following breakup of the spring

ice algal bloom (Cooper et al. 2009; Pirtle-Levy et al. 2009). However, to our knowledge, correlations between phytoplankton or ice algal production with sedimentary pigments have not been studied throughout the ice-covered season. In polar regions, the production by sea-ice algae, especially diatoms, can be the main source of carbon for pelagic and benthic food webs (Gosselin et al. 1997; Nozais et al. 2001; Arrigo 2003).

In the present study, both chl $a$ and fucoxanthin concentrations increased in the bottom ice layer and the water column from January/February to April/May (Fig. 2a-d), indicating a biomass increase in ice algae and more specifically, diatoms. The ice algal community in Franklin Bay was dominated by the pennate diatoms Nitzschia frigida, $N$. promare Medlin, Navicula sp. 6 and N. pelagica, which increased steadily from February to May (Różańska et al. 2009). However, the very low chl $a$ concentrations $\left(<0.02 \mathrm{mg} \mathrm{L}^{-1}\right)$ in the water column (Fig. 2a) confirmed the dominance of ice algae as the main carbon source for the 

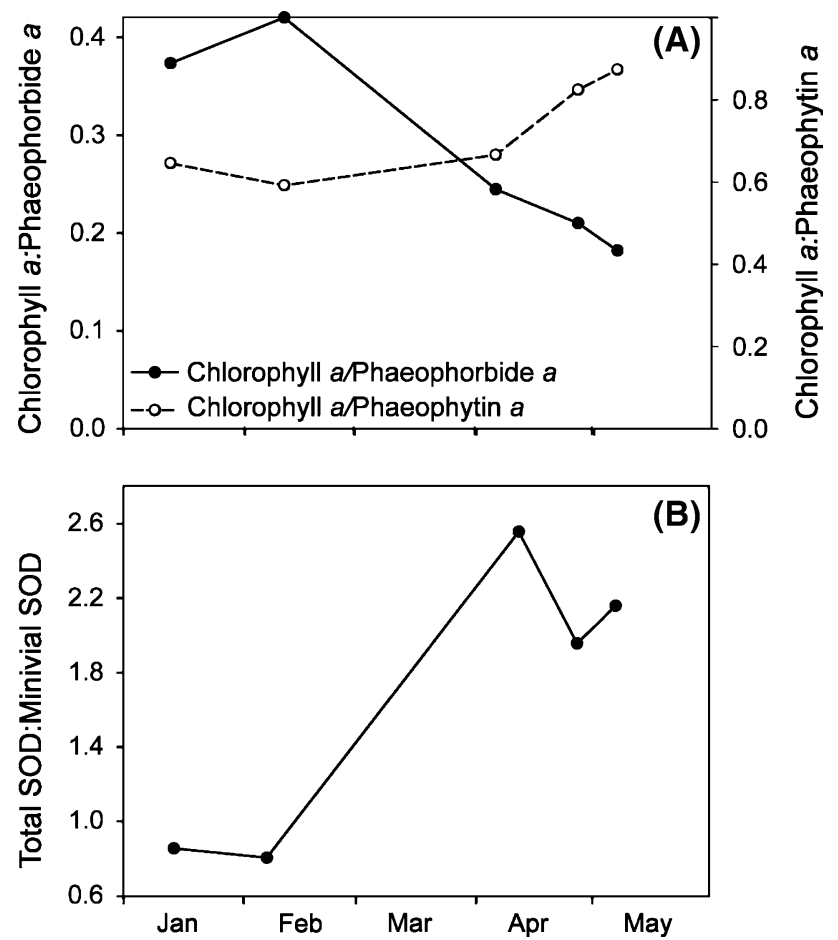

Fig. 3 Temporal variations of a ratios of sedimentary chlorophyll $a$ (chl $a$ ) to phaeophorbide $a$ and $\operatorname{chl} a$ to phaeophytin $a$, and $\mathbf{b}$ ratio of total sediment oxygen demand (SOD) to minivial SOD in Franklin Bay from January to May 2004. SOD data were from Renaud et al. (2007). Ratio $<1$ in January/February is due to methodological overestimation of minivial SOD (see Grant et al. 2002 for further information)

pelagic and benthic food web. Vertical fluxes of POM increased in the upper $25 \mathrm{~m}$ of the water column from midMarch (Renaud et al. 2007; Juul-Pedersen et al. 2008). During the spring, the sinking of algal cells also increased, and cells were mainly the same sea-ice pennate diatoms recorded in trap samples (i.e. Nitzschia frigida and Navicula spp., A. Tatarek personal communication). Similarly, POM fluxes at $200 \mathrm{~m}$ in Franklin Bay increased in the spring, and ice algae likely contributed significantly to this increase (Forest et al. 2008).

Grazing by zooplankton can strongly impact downward fluxes of POM produced in the surface layer of the water column (Olli et al. 2002; Wexels Riser et al. 2008). A higher degradation of fresh algal biomass is expected to increase the relative amount of chlorophyll degradation products (Welschmeyer 1985), which can be detected in the sediment by a change in the chl $a$ :phaeo ratio. However, some studies have reported that copepods do not feed at chl $a$ concentration $<1 \mu \mathrm{g} \mathrm{L}^{-1}$ (Frost 1972; Gamble 1978; Saunders et al. 2003). In the present study, at the deep chl $a$ maximum, no such chl $a$ concentrations were attained. Seuthe et al. (2007) observed an increase in the zooplankton fecal pellet production during this same period but they suggested that this was probably due to additional
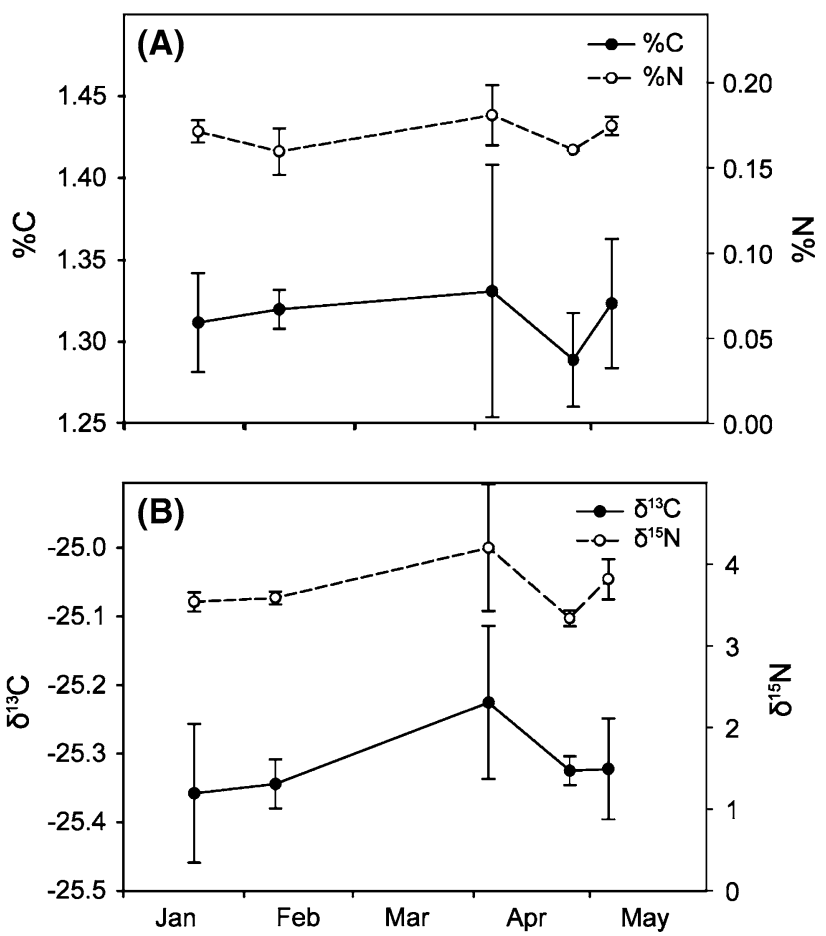

Fig. 4 Temporal variations of a percentage of organic carbon (\%C) and nitrogen $(\% \mathrm{~N})$ in the sediment, and $\mathbf{b}$ sedimentary stable isotope $\delta^{13} \mathrm{C}$ and $\delta^{15} \mathrm{~N}$ composition. Mean values $\pm \mathrm{SD}(n=3)$ are shown

non-pigmented sources of food, such as microzooplankton. No grazing degradation products were identified during fecal pellet production experiments (N. Morata, unpublished data). All of these suggest that the grazing occurring in the water column may not significantly impact the algal biomass during the early spring and it is probably not a source of input of degraded material to the sea floor. Consequently, the increase in sedimentary chl a:phaeophorbide $a$ ratio is likely due to higher inputs of fresher algal material.

The increase in ice algal biomass throughout the spring and the inefficient control of the ice algal biomass by pelagic grazers may contribute to higher inputs of fresh organic matter to the benthos in April/May. Frustules of ice algae have been previously recorded in the sediment of Arctic shelves (Sancetta 1981; Cremer 1999; Djinoridze et al. 1999; Polyakova 2003; Ambrose et al. 2005) or have been suspected to occur due to observations of high concentrations of chl $a$ and/or fucoxanthin (Schewe and Soltwedel 2003; Morata and Renaud 2008; Morata et al. 2008; Pirtle-Levy et al. 2009). Here, the percentage of empty and viable pennate diatoms increased (Fig. 7), and Nitzschia frigida and Navicula spp. dominated the diatom composition in ice algal communities and sediment traps (Różańska et al. 2009; A. Tatarek, personal communication) as well as in sediment samples. The ratio of sedimentary chl $a$ :phaeo also increased, reflecting higher inputs of sinking algae as 
Fig. 5 Vertical profiles of sedimentary chlorophyll $a(\operatorname{chl} a)$ and ratio of $\operatorname{chl} a$ to phaeopigment over the first $10 \mathrm{~cm}$ of sediment in Franklin Bay from January to May 2004. Mean values $\pm \mathrm{SD}(n=3)$ are shown

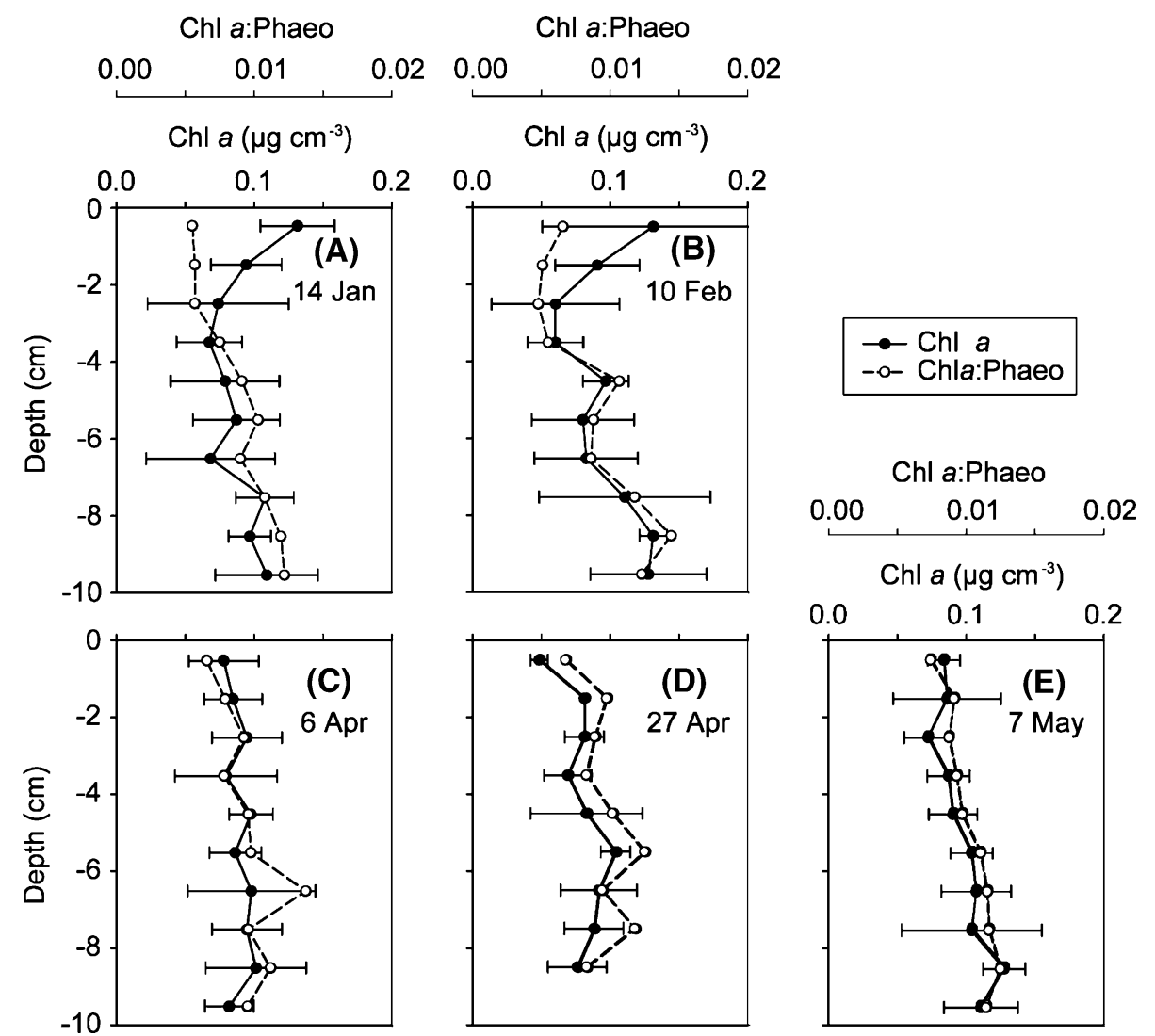

fresher phytodetritus; however, the chl $a$ and fucoxanthin concentrations showed no increase. Sedimentary pigments, then, only reflected the increase in the "quality" and not the quantity of phytodetritus. Only the number of diatom cells showed the increase in quantity (Table 1; Fig. 7).

Stable isotopes have been used in marine systems to estimate the inputs of terrestrial and marine organic carbon to the sediment (Naidu et al. 1993; Goni et al. 2000) and to trace the energy pathways from different sources of primary production (including ice algae) through the pelagic food web (Hobson et al. 1995; Tamelander et al. 2006, 2008). In the present study, stable isotopes, $\% \mathrm{~N}$, and $\% \mathrm{C}$ did not show substantial variations from January to May (Fig. 4). Stable isotopes and percentages of carbon and nitrogen integrate the signal of the overall organic matter present in the sediment over a period of months and thus are probably not good indicators of short-term changes in the vertical flux of the organic material to the sea floor in Franklin Bay. Organic carbon represented about $1.3 \%$ of the dry weight sediment, while sedimentary chl $a$ only represented $<0.03 \%$ of the dry weight sediment. Changes in the signal of the sedimentary phytodetritus may, therefore, be lost when studying bulk sediment parameters. Our first hypothesis is thus partially confirmed. The abundance of diatom frustules (empty and viable cells) and chl $a$ :phaeo ratio reflected the increase in ice algal phytodetritus to the sea floor, but the data from other biomarkers were inconclusive. Consequently, in Franklin Bay, only the overall increase in the phytodetritus quality can be studied using detailed pigment analysis but not with biomarkers of bulk organic material.

$\mathrm{H} 2$ : The increase in food inputs to the sediment stimulates the benthos, resulting in a quick increase in benthic activity, bioturbation, and pigment degradation products

Sediment communities have been reported to quickly respond to pulses of phytodetritus reaching the sea floor by increasing their consumption of oxygen (Witte et al. 2003; Renaud et al. 2008). High SOD values have been recorded in April/May in Franklin Bay by Renaud et al. (2007) as a possible consequence of increasing ice algal inputs.

Increasing food availability can increase foraging activity by benthic animals (Jumars and Wheatcroft 1989; Maire et al. 2006), which can affect sediment profiles of pigments and other constituents. Moreover, chl $a$ :phaeo ratios can be used as indicators of the degradation of organic matter (Boon and Duineveld 1996). In Franklin Bay, the lowest chl $a$ :phaeo ratios were always measured in the top centimeter of the sediment (Fig. 6b) compared to the average values over the 5 or 10 top centimeters. As fresh phytodetritus is always introduced to the sediment, these lower chl $a$ :phaeo ratios suggest a rapid use of the surface organic 

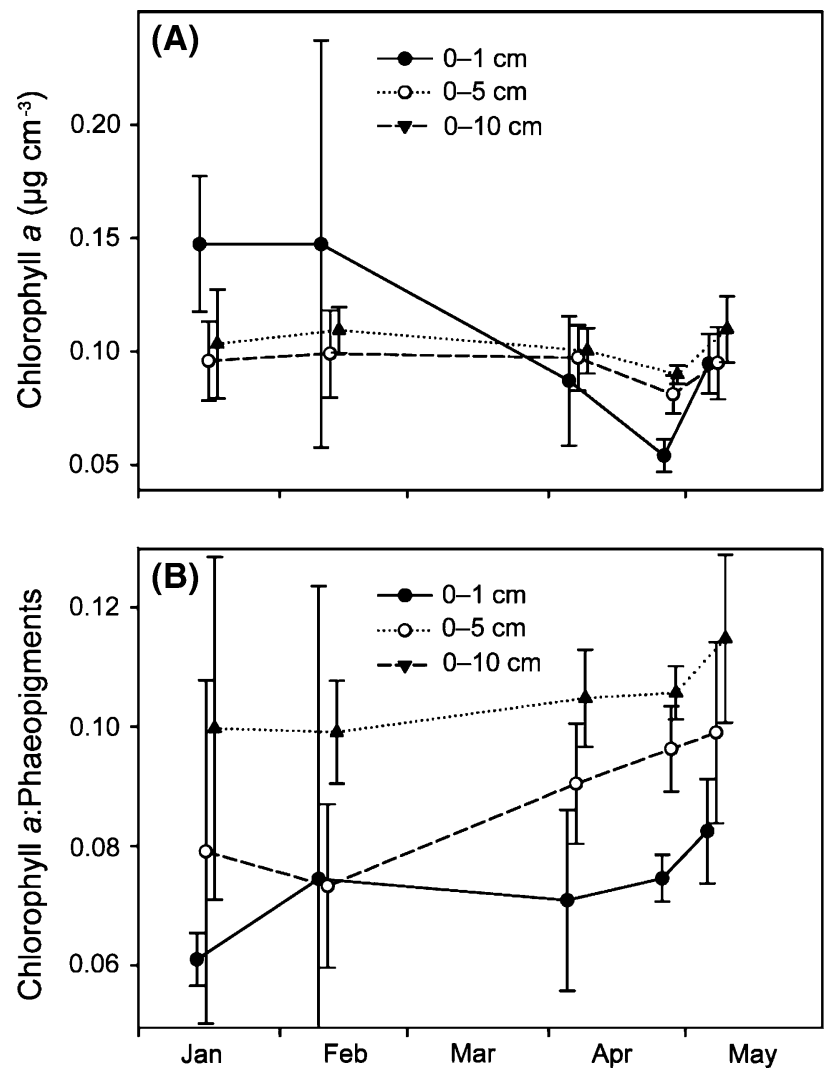

Fig. 6 Temporal variations of a chlorophyll $a$ concentration and b ratio of chlorophyll $a$ to phaeopigment in the $0-1,0-5$ and $0-10 \mathrm{~cm}$ of sediment in Franklin Bay from January to May 2004. Mean values $\pm \mathrm{SD}$ are shown

matter, a quick burial of the fresh phytodetritus underneath the surface sediment, or both.

In low bioturbation conditions, sedimentary chl $a$ concentrations exhibit an exponential decrease with depth, whereas irregular pigment profiles can occur due to non-diffusive mixing by benthic organisms (Sun et al. 1994). Sedimentary pigment profiles (Fig. 5) changed in Franklin Bay from a decrease with depth in January/February (Fig. 5a, b) to a more homogeneous distribution in April/May (Fig. 5c-e). The change in sedimentary chl $a$ profile can also be observed when comparing the top $\mathrm{cm}$ with the average values for the first 5 and 10 top centimeters (Fig. 6a). Chl $a$ concentration in the top first $\mathrm{cm}$ decreased over time, while the average values over the first 5 and 10 top centimeters remained more stable, suggesting a transport of the sedimentary pigments in April/May compared to January/February. While the calculation of bioturbation rate would require sedimentation and decomposition rate values, the change in sedimentary chl $a$ concentrations with depth, and the increase through time of the chl $a$ :phaeo ratio in the top $5 \mathrm{~cm}$, suggest an increase in particle mixing.

In Franklin Bay, the fauna consists of a mud-associated community mainly dominated by the deep burrowing

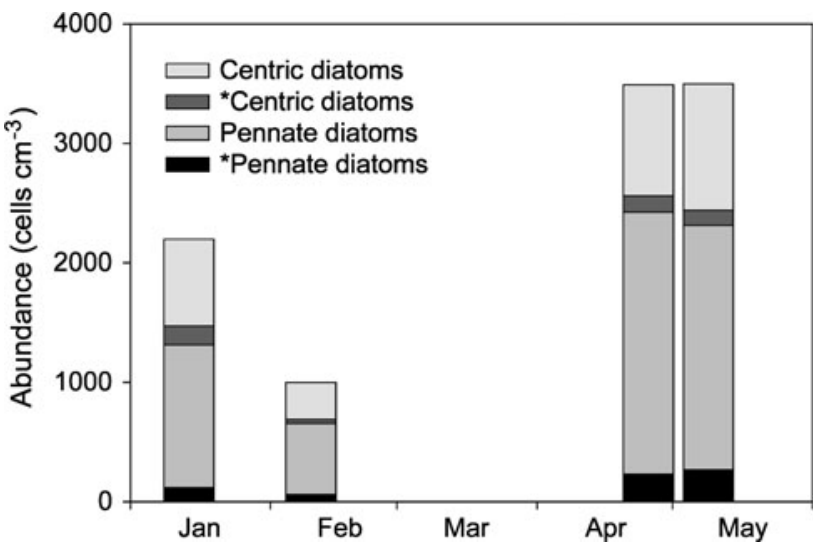

Fig. 7 Temporal variations in the relative abundance of viable (with chloroplasts) and empty centric and pennate diatoms in the sediment in Franklin Bay from January to May 2004. * Indicates viable species

polychaete Maldane sarsi Malmgren and other common species, including other polychaetes (Tharyx kirkegaardi Blake + T. marioni St. Joseph, Lumbrineris impatiens (Claparède), Prionospio cirrifera Wiren $+P$. steenstrupi Malmgren), ostracods (Podocopid 1a, Philomedes brenda (Baird)) and bivalves (Thyasira flexuosa (Montagu), Portlandia spp.) (Conlan et al. 2008). The polychaete Maldane sarsi is a deep burrowing, head-down, non-selective deposit feeder that defecates at the surface and, therefore, is probably important in non-local sediment mixing, pore water oxygenation and surface nutrient replenishment (Holte 1998). Enhanced benthic activity (SOD) in April/ May may have contributed to higher bioturbation as many benthic organisms increase burrowing activities. Previous studies have shown that the benthos can use rapidly ice algae as food source (McMahon et al. 2006; Sun et al. 2009). The lack of an increase in sedimentary chl $a$ concentration in the present study may, then, be a result of the rapid use of phytodetrital inputs due to a higher benthic activity, as suggested in Renaud et al. (2007), combined with a reworking and burial of the sedimented organic material. We can consider our second hypothesis as being mostly confirmed even though it remains uncertain how the vertical inputs of fresh ice algae are degraded, as, for example, the uncolored chl $a$ degradation products are not identifiable by HPLC.

H3: Some groups of organisms are stimulated by fresh inputs more than others (macrofauna vs. bacteria)

Compared to temperate regions, the Arctic macrobenthos has an enhanced role in benthic carbon cycling relative to the meio- and microfauna (Piepenburg et al. 1995; Clough et al. 2005; Renaud et al. 2008). Partitioning of benthic metabolism, however, has been found to vary seasonally depending on the trophic conditions of the system, i.e. oligotrophic 
Table 1 Abundance of viable (with chloroplasts) and empty diatoms in cells $\mathrm{cm}^{-3}$, with their relative proportion in parenthesis, in the first $2 \mathrm{~cm}$ of sediment under first-year landfast ice in Franklin Bay in winter and spring 2004

Only species representing more than $1 \%$ of the total cell numbers at a given date are presented

* Indicates viable species

\begin{tabular}{|c|c|c|c|c|}
\hline & $\begin{array}{l}14 \mathrm{Jan} \\
\mathrm{cm}^{-3}(\%)\end{array}$ & $\begin{array}{l}10 \mathrm{Feb} \\
\mathrm{cm}^{-3}(\%)\end{array}$ & $\begin{array}{l}29 \mathrm{Apr} \\
\mathrm{cm}^{-3}(\%)\end{array}$ & $\begin{array}{l}9 \text { May } \\
\mathrm{cm}^{-3}(\%)\end{array}$ \\
\hline Diploneis spp. & 0 & 0 & $314(9.0)$ & $139(4.0)$ \\
\hline $\begin{array}{l}\text { *Fossula arctica Hasle, } \\
\text { Syvertsen \& von Quillfeldt }\end{array}$ & 0 & 0 & 0 & $69(2.0)$ \\
\hline Fossula arctica & 0 & $16(1.6)$ & $46(1.3)$ & 0 \\
\hline Fragilariopsis cylindrus (Cleve) Frenguelli & $303(13.8)$ & $202(20.2)$ & $661(18.9)$ & $939(26.8)$ \\
\hline Fragilariopsis oceanica (Cleve) Hasle & $41(1.9)$ & 0 & 0 & 0 \\
\hline *Navicula pelagica Cleve & $52(2.4)$ & $24(2.4)$ & $216(6.2)$ & 0 \\
\hline *Navicula vanhoeffenii Gran & 0 & $12(1.2)$ & 0 & 0 \\
\hline Navicula spp. & $70(3.2)$ & $47(4.7)$ & $111(3.2)$ & $233(6.7)$ \\
\hline Nitzschia frigida Grunow & $169(7.7)$ & $79(7.9)$ & $111(3.2)$ & $57(1.6)$ \\
\hline Nitzschia neofrigida Medlin & $23(1.1)$ & 0 & 0 & 0 \\
\hline Nitzschia spp. & $47(2.1)$ & $16(1.6)$ & $39(1.1)$ & 0 \\
\hline $\begin{array}{l}\text { Pseudogomphonema arcticum } \\
\text { (Grunow) Medlin }\end{array}$ & $146(6.6)$ & $43(4.3)$ & $105(3.0)$ & $44(1.3)$ \\
\hline *Unidentified pennate cells & $94(4.3)$ & $36(3.6)$ & $177(5.5)$ & $163(4.7)$ \\
\hline Unidentified pennate cells & $367(16.7)$ & $166(16.6)$ & $635(17.0)$ & $617(18.1)$ \\
\hline Chaetoceros spp. & $29(1.3)$ & $16(1.6)$ & 0 & 0 \\
\hline *Leptocylindrus minimus Gran & $58(2.7)$ & 0 & 0 & 0 \\
\hline *Melosira arctica Dickie & $29(1.3)$ & $12(1.2)$ & $33(1.0)$ & 0 \\
\hline *Thalassiosira spp. & $82(3.7)$ & 0 & $79(2.3)$ & $69(2.0)$ \\
\hline Thalassiosira spp. & $641(29.2)$ & $206(20.6)$ & $615(17.6)$ & $737(21.1)$ \\
\hline *Unidentified centric cells & $17(1.0)$ & $35(3.6)$ & $59(1.7)$ & $82(2.4)$ \\
\hline Unidentified centric cells & $23(1.1)$ & $87(8.7)$ & $314(8.9)$ & $321(9.4)$ \\
\hline
\end{tabular}

vs. meso-eutrophic (Gooday 2002). In the North Water Polynya in the eastern Canadian Arctic, the meio- and microbenthos dominated oxygen consumption in the spring, while the macrofauna was responsible for the greatest oxygen consumption in the summer (Grant et al. 2002).

From January/February to April/May, the total SOD increased 10 times, while the minivial SOD showed only two time increase (Renaud et al. 2007). The minivial incubations overestimated the bacterial activity since the sediment exposure to oxygenated waters can break up nutrient microgradients and redox conditions, therefore, possibly enhancing bacterial oxygen demand (Grant et al. 2002). However, the increase in the total SOD:minivial SOD ratio over time suggested an increase in the macrofaunal oxygen demand.

Both macrozooplankton and macrobenthos remove the phytol chain of chl $a$ during grazing (Prahl et al. 1984; Harvey et al. 1987), resulting in the creation of phaeophorbide $a$ degradation products (Leavitt 1993). Conversely, the microzooplankton or the bacteria cannot efficiently remove the phytol chain of $\operatorname{chl} a$, resulting in the creation of phaeophytin $a$ instead of phaeophorbide $a$ (Verity and Vernet 1992; Leavitt 1993). During our study, the chl $a$ :phaeophorbide $a$ ratio decreased while chl $a$ :phaeophytin $a$ increased (Fig. 3). Although phaeophorbides were used to trace grazing processes in both the water column (Jeffrey 1974; Carpenter et al. 1986; Spooner et al. 1994) and the sediment (Brotas and Plante-Cuny 1998; Riaux-Gobin et al. 2000), it has recently been argued that they may not always be a relevant indicator of herbivorous activities (Villanueva and Hastings 2000; Ford and Honeywill 2002). The chl $a$ :phaephorbide $a$ ratio by itself does not allow to conclude to a relative enhancement of the macrofauna activities. However, combined with the SOD results, the present study suggests that the macrobenthic activity is enhanced by the pulse of ice algal phytodetritus to a greater extent than bacteria and microfauna, therefore supporting our third hypothesis.

\section{Conclusion}

The present study tested three non-exclusive hypotheses explaining the responses of sediment communities to an input of ice algae to the sea floor. The first hypothesis was partially refuted; although an increase in the abundance of ice diatom frustules and the chl $a$ :phaeo ratio was observed, the arrival of fresh ice algal phytodetritus did not lead to a measurable increase in sedimentary chl $a$ or fucoxanthin. The second and third hypotheses were mainly confirmed. 
When more and fresher ice algal phytodetritus reached the sea floor, the macrobenthos was stimulated, and increased its respiration and sediment bioturbation, leading to changes in pigment profiles and degradation of pigments. None of the three hypotheses can by itself explain how sedimentary pigments would reflect the pulse of ice algae. In highly productive ecosystems, the signal of freshly deposited material may not be affected by the partial loss of this signal to benthic activities. However, when studying less productive non steady-state ecosystems, such as some Arctic seas during the ice-covered spring bloom, it is thus important to consider the three types of responses and choose the right biomarkers or indicators. Studying single traditional parameters of the quality of organic matter to the sea floor, such as sedimentary chl $a$ or stable isotopes, carbon and nitrogen contents, might not be sufficient. Multiple biological and biochemical biomarkers that indicate sources, mixing, and fate must be employed if questions about complex processes are to be solved.

Acknowledgments This work would not have been possible without the efforts of the captain G. Tremblay, officers, and crew of the CCGS Amundsen. We would like especially to thank chief scientists $\mathrm{J}$. Deming, T. Papakyriakou, and L. Fortier, and all the CASES scientists, especially the ones who helped with the gigantic task of cutting the ice for deploying the box corer. Many thanks are due to A. Aitken, S. Brugel, T. Connelly, G. Darnis, A. Forest, M. Gosselin, C. Guignard, T. Juul-Pedersen, M. Lizotte, C. McClelland, P. Massot, L. Michaud, J. Payet, A. Riedel, M. Różańska, A. Tatarek, and J. Wiktor. We are extremely grateful to J. Perl (San Diego State University Research Foundation) for providing pigment standards. Thank you very much to L. Cooper (University of Maryland) for sharing results and methods with us, and to B. Johnson for stable isotope analysis. Thanks are also due to P. B. Hamilton (Canadian Museum of Nature) for his precious help and insights into diatom study. Comments from Glenn Lopez and one anonymous reviewer improved the manuscript. This research was funded by grants from the National Science Foundation (OPP-0326371) and Connecticut Sea Grant to PER, and the UCONN Department of Marine Sciences and Statoil to NM. This work was supported from grants from the Natural Sciences and Engineering Research Council (NSERC) of Canada (Research Network and Individual Discovery grants to M.P.) and by financial support from the Canadian Museum of Nature to M.P. Partial operating funds for the CCGS Amundsen were provided by the International joint Ventures Fund of the Canada Foundation for Innovation and the Fonds québécois de la recherche sur la nature et les technologies (FQRNT). This work is a contribution to the research program of the Canadian Arctic Shelf Exchange Study.

Open Access This article is distributed under the terms of the Creative Commons Attribution Noncommercial License which permits any noncommercial use, distribution, and reproduction in any medium, provided the original author(s) and source are credited.

\section{References}

Ambrose WG Jr, von Quillfeldt C, Clough LM, Tilney PVR, Tucker T (2005) The sub-ice algal community in the Chukchi sea: largeand small-scale patterns of abundance based on images from a remotely operated vehicle. Polar Biol 28:784-795
Arrigo KR (2003) Primary production in sea ice. In: Thomas DN, Dieckmann GS (eds) Sea ice: an introduction to its physics, chemistry, biology and geology. Blackwell, Oxford, pp 143-183

Bessière A, Nozais C, Brugel S, Demers S, Desrosiers G (2007) Metazoan meiofauna dynamics and pelagic-benthic coupling in the Southeastern Beaufort Sea, Arctic Ocean. Polar Biol 30:11231135

Blanchard G, Chrétiennot-Dinet M-J, Dinet A, Robert J-M (1988) Méthode simplifiée pour l'extraction du microphytobenthos des sédiments marins par le gel de silice Ludox. Biol Mar 307:569576

Boetius A, Damm E (1998) Benthic oxygen uptake, hydrolytic potentials and microbial biomass at the Arctic continental slope. DeepSea Res I 45:239-275

Boon AR, Duineveld GCA (1996) Phytopigments and fatty acids as molecular markers for the quality of near-bottom particulate organic matter in the North Sea. J Sea Res 35:279-291

Brotas V, Plante-Cuny MR (1998) Spatial and temporal patterns of microphytobenthic taxa of estuarine tidal flats in the Tagus estuary (Portugal) using pigment analysis by HPLC. Mar Ecol Prog Ser $171: 43-57$

Carpenter SR, Elser MM, Elser KK (1986) Chlorophyll production, degradation, and sedimentation: implication for sedimentology. Limnol and Oceanogr 31:112-124

Carroll ML, Carroll J (2003) The Arctic Seas. In: Black KD, Shimmield GB (eds) Biogeochemistry of marine systems. Blackwell Publishing, Oxford, pp 126-156

Chen NH, Bianchi TS, McKee BA, Bland JM (2001) Historical trends of hypoxia on the Louisiana shelf: application of pigments as biomarkers. Org Geochem 32:543-561

Clough LM, Renaud PE, Ambrose WG Jr (2005) Impacts of water depth, sediment pigment concentration, and benthic macrofaunal biomass on sediment oxygen demand in the western Arctic Ocean. Can J Fish Aquat Sci 62:1756-1765

Conlan K, Aitken A, Hendrycks E, McClelland C, Melling H (2008) Distribution patterns of Canadian Beaufort Shelf macrobenthos. J Mar Syst 74:864-886

Cooper LW, Lalande C, Pirtle-Levy R, Larsen IL, Grebmeier JM (2009) Seasonal and decadal shifts in particulate organic matter processing and sedimentation in the Bering Strait Shelf region. Deep-Sea Res II 56:1316-1325

Cremer H (1999) Spatial distribution of diatom surface sediment assemblages on the Laptev Sea shelf (Russian Arctic). In: Kassens H, Bauch HA, Dmitrenko I, Eicken H, Hubberten K-W, Melles M, Thiede J, Timokhov L (eds) Land-ocean systems in the Siberian Arctic: dynamic and history. Springer, Berlin, pp 533551

Djinoridze RN, Ivanov GI, Djinoridze EN, Spielhagen RF (1999) Diatoms from surface sediments of the Saint Anna Trough (Kara Sea). In: Kassens H, Bauch HA, Dmitrenko I, Eicken H, Hubberten K-W, Melles M, Thiede J, Timokhov L (eds) Land-ocean systems in the Siberian Arctic: dynamic and history. Springer, Berlin, pp 553-560

Ford RB, Honeywill C (2002) Grazing on intertidal microphytobenthos by macrofauna: is phaeophorbide a useful marker? Mar Ecol Prog Ser 229:33-42

Forest A, Sampei M, Makabe R, Sasaki H, Barber DG, Gratton Y, Wassmann P, Fortier L (2008) The annual cycle of particulate organic carbon export in Franklin Bay (Canadian Arctic): environmental control and food web implications. J Geophys Res 113(C3):C03S05. doi:10.1029/2007JC004262

Frost BW (1972) Effects of size and concentration of food particles on the feeding behavior of the marine planktonic copepod Calanus pacificus. Limnol Oceanogr 17:805-815

Gamble JC (1978) Copepod grazing during a declining spring phytoplankton bloom in the northern North Sea. Mar Biol 49:303-315 
Garrison DL, Buck KR (1986) Organism losses during ice melting: a serious bias in sea ice community studies. Polar Biol 6:237-239

Gieskes WWC, Kraay GW (1984) Phytoplankton, its pigments, and primary production at a central North Sea station in May, July and September 1981. Netherlands J Sea Res 18:51-70

Goni MA, Yunker MB, Macdonald RW, Eglinton TI (2000) Distribution and sources of organic biomarkers in arctic sediments from the Mackenzie River and Beaufort Shelf. Mar Chem 71:23-51

Gooday AJ (2002) Biological responses to seasonally varying fluxes of organic matter to the ocean floor: a review. J Oceanogr 58(2002): 305-332

Gosselin M, Levasseur M, Wheeler PA, Horner RA, Booth BC (1997) New measurements of phytoplankton and ice algal production in the Arctic Ocean. Deep-Sea Res II 44:1623-1644

Grant J, Hargrave B, MacPherson P (2002) Sediment properties and benthic-pelagic coupling in the North Water. Deep-Sea Res II 49:5259-5275

Günther S, Dieckmann GS (1999) Seasonal development of algal biomass in snow-covered fast ice and the underlying platelet layer in the Weddell Sea, Antarctica. Antarctic Sci 11:305-315

Hamilton PB, Proulx M, Earle C (2002) Enumerating phytoplankton with an upright compound microscope using a modified settling chamber. Hydrobiologia 444:171-175

Hamilton SK, Sippel SJ, Bunn SE (2005) Separation of algae from detritus for stable isotope and ecological stochiometry studies using density fractionation in colloidal silica. Limnol Oceanogr Methods 3:149-157

Harvey HR, Eglinton G, O’Hara SCM, Corner EDS (1987) Biotransformation and assimilation of dietary lipids by Calanus feeding on a dinoflagellate. Geochim Cosmochim Acta 51:3031-3040

Hobson KA, Ambrose WG Jr, Renaud PE (1995) Sources of primary production, benthic-pelagic coupling, and trophic relationships within the Northeast Water Polynya: insights from delta ${ }^{13} \mathrm{C}$ and delta ${ }^{15} \mathrm{~N}$ analysis. Mar Ecol Prog Ser 128:1-10

Holm-Hansen O, Lorenzen CJ, Holms RW, Strickland JD (1965) Fluorometric determination of chlorophyll. J Cons Int Explor Mer 30:3-15

Holte B (1998) The macrofauna and main functional interactions in the sill basin sediments of the pristine Holandsfjord, North Norway, with autecological reviews for some key-species. Sarsia 83:55-68

Jeffrey SW (1974) Profiles of photosynthetic pigments in the ocean using thin layer chromatography. Mar Biol 26:101-110

Jeffrey SW, Mantoura RFC (1997) Development of pigment methods for oceanography: SCOR-supported Working Groups and objectives. In: Jeffrey SW, Mantoura RFC (eds) Phytoplankton pigments in oceanography. UNESCO, Paris, pp 19-36

Jumars PA, Wheatcroft RA (1989) Responses of benthos to changing food quality and quantity, with a focus on deposit feeding and bioturbation. In: Berger WH, Smetacek VS, Wefer G (eds) Productivity in the ocean: present and past. Wiley, New York, pp 235-253

Juul-Pedersen T, Michel C, Gosselin M, Seuthe L (2008) Seasonal changes in the sinking export of particular material, under firstyear sea ice on the Mackenzie Shelf (western Canadian Arctic). Mar Ecol Prog Ser 353:13-25

Leavitt PR (1993) A review of factors that regulate carotenoid and chlorophyll deposition and fossil pigment abundance. J Paleolimnol 9:109-127

Legendre L, Ackley SF, Dieckmann GS, Gulliksen B, Horner R, Hoshiai T, Melnikov IA, Reeburgh WS, Spindler M, Sullivan CW (1992) Ecology of sea ice biota: 2. Global significance. Polar Biol $12: 429-444$

Lizotte MP (2003) The microbiology of sea ice. In: Thomas DN, Dieckmann GS (eds) Sea ice: an introduction to its physics, chemistry, biology and geology. Blackwell, Oxford, pp 184210
Maire O, Duchêne JC, Rosenberg R, de Mendonça JB, Grémare A (2006) Effects of food availability on sediment reworking in Abra ovata and A. nitida. Mar Ecol Prog Ser 319:135-153

Mantoura RFC, Llewellyn CA (1983) The rapid determination of algal chlorophyll and carotenoid pigments and their breakdown products in natural waters by reverse-phase high-performance liquid chromatography. Anal Chim Acta 151:297-314

McMahon KW, Ambrose WG Jr, Johnson BJ, Sun M-Y, Lopez GR, Clough LM, Carroll ML (2006) Benthic community response to ice algae and phytoplankton in Ny Ålesund, Svalbard. Mar Ecol Prog Ser 310:1-14

Michel C, Legendre L, Ingram R, Gosselin M, Levasseur M (1996) Carbon budget of sea-ice algae in spring: evidence of a significant transfer to zooplankton grazers. J Geophys Res 101(8):1834518360

Michel C, Nielsen TG, Nozais C, Gosselin M (2002) Significance of sedimentation and grazing by ice micro- and meiofauna for carbon cycling in annual sea ice (northern Baffin Bay). Aquat Microb Ecol 30:57-68

Morata N, Renaud PE (2008) Sedimentary pigments in the western Barents Sea: a reflection of the pelagic-benthic coupling? Deep-Sea Res II 55:2381-2389

Morata N, Renaud PE, Brugel S, Hobson KA, Johnson BJ (2008) Spatial and seasonal variations in the pelagic-benthic coupling of the southeastern Beaufort Sea revealed by sedimentary biomarkers. Mar Ecol Prog Ser 371:47-63

Naidu AS, Scalan RS, Feder HM, Goering JJ, Hameedi MJ, Parker PL, Behrens EW, Caughey ME SCJ (1993) Stable organic carbon isotope in sediments of the north Bering-south Chukchi seas, Alaskan-Soviet Arctic Shelf. Cont Shelf Res 13:669-691

Nozais C, Gosselin M, Michel C, Tita G (2001) Abundance, biomass, composition and grazing impact of the sea-ice meiofauna in the North Water, northern Baffin Bay. Mar Ecol Prog Ser 217:235250

Olli K, Wexels Riser C, Wassmann P, Ratkova T, Arashkevich E, Pasternak A (2002) Seasonal variation in vertical flux of biogenic matter in the marginal ice zone and the central Barents Sea. J Mar Syst 38:189-204

Pfannkuche O, Thiel H (1987) Meiobenthic stocks and benthic activity on the NE-Svalbard shelf and in the Nansen Basin. Polar Biol 7:253-266

Piepenburg D, Blackburn TH, von Dorrien CF, Gutt J, Hall POJ, Hulth S, Kendall MA, Opalinski KW, Rachor E, Schmid MK (1995) Partitioning of benthic community respiration in the Arctic (northwestern Barents Sea). Mar Ecol Prog Ser 118:199-213

Pirtle-Levy R, Grebmeier JM, Cooper LW, Larsen IL, DiTullio GR (2009) Chlorophyll $a$ in Arctic sediments implies long persistence of algal pigments. Deep-Sea Res II 56:1326-1338

Polyakova YI (2003) Diatom assemblages in surface sediments of the Kara Sea (Siberian Arctic) and their relationship to oceanological conditions. In: Stein R, Fahl K, Futterer DK, Galimov AM, Stepanets OV (eds) Siberian river run-off in the Kara Sea: characterisation, quantification, variability and environmental significance, vol 6. Elsevier, Amsterdam, pp 375-399

Prahl FG, Eglinton G, Corner EDS, O'Hara SCM (1984) Copepod fecal pellets as a source of dihydrophytol in marine sediment. Science 224:1235-1237

Renaud PE, Morata N, Carroll ML, Denisenko SG, Reigstad M (2008) Benthic-pelagic coupling in the western Barents Sea: processes and time scales. Deep-Sea Res II 55:2372-2380

Renaud PE, Riedel A, Michel C, Morata N, Gosselin M, Juul-Pedersen T, Chiuchiolo A (2007) Seasonal variation in benthic community oxygen demand: a response to an ice algal bloom in the Beaufort Sea, Canadian Arctic? J Mar Syst 67:1-12

Riaux-Gobin C, Klein B, Duchêne J-C (2000) A pigment analysis of feeding modes of Thelepus extensus (Polychaeta, Terebellidae) in 
relation to wave exposure at the Îles Kerguelen. Antarct Sci 12:52-63

Riedel A, Michel C, Gosselin M (2006) Seasonal study of sea-ice exopolymeric substances on the Mackenzie shelf: implication for transport of sea-ice bacteria nd algae. Aquat Microb Ecol 45:195206

Różańska M, Gosselin M, Poulin M, Wiktor JM, Michel C (2009) Influence of environmental factors on the development of bottom ice protist communities during the winter-spring transition. Mar Ecol Prog Ser 386:43-59

Sakshaug E (2004) Primary and secondary production in the Arctic Seas. In: Stein R, Macdonald RW (eds) The Arctic carbon cycle in the Arctic Ocean. Springer, Berlin, pp 57-81

Sancetta C (1981) Diatoms as hydrographic tracers: example from Bering Sea sediment. Science 211:279-281

Saunders KM, Deibel D, Stevens CJ, Rivkin RB, Lee SH, Klein B (2003) Copepod herbivory rate in a large Arctic polynya and its relationship to seasonal and spatial variation in copepod and phytoplankton biomass. Mar Ecol Prog Ser 261:183-199

Schewe I, Soltwedel T (2003) Benthic response to ice-edge-induced particle flux in the Arctic Ocean. Polar Biol 26:610-620

Seuthe L, Darnis G, Wexels Riser C, Wassmann P, Fortier L (2007) Winter-spring feeding and metabolism of Arctic copepods: insights from faecal pellet production and respiration measurements in the southeastern Beaufort Sea. Polar Biol 30:427-436

Spooner N, Keely BJ, Maxwell JR (1994) Biologically mediated defunctionalization of chlorophyll in the aquatic environment I: senescence/decay of the diatom Phaeodactylum tricornutum. Org Geochem 22:773-780

Sun M-Y, Aller RC, Lee C (1994) Spatial and temporal distributions of sedimentary chloropigments as indicators of benthic processes in Long Island Sound. J Mar Res 52:149-176

Sun M, Clough LM, Carroll ML, Dai J, Ambrose WG Jr, Lopez GR (2009) Different responses of two common Arctic macrobenthic species (Macoma balthica and Monoporeia affinis) to phytoplankton and ice algae: will climate change impacts be species specific? J Exp Mar Biol Ecol 376:110-121
Tamelander T, Renaud PE, Hop H, Carroll ML, Ambrose WG Jr, Hobson KA (2006) Trophic relationships and pelagic-benthic coupling during summer in the Barents Sea Marginal Ice Zone revealed by stable carbon and nitrogen measurements. Mar Ecol Prog Ser 310:33-46

Tamelander T, Reigstad M, Hop H, Carroll ML, Wassmann P (2008) Pelagic and sympagic contribution of organic matter to zooplankton and vertical export in the Barents Sea marginal ice zone. Deep-Sea Res II 55:2330-2339

Verity PG, Vernet M (1992) Microzooplanton grazing, pigments, and composition of plankton communities during late spring in two Norwegian fjords. Sarsia 77:263-274

Villanueva J, Hastings DW (2000) A century-scale record of the preservation of chlorophyll and its transformation products in anoxic sediments. Geochim Cosmochim Acta 64:2281-2294

von Quillfeldt CH, Ambrose WG, Clough LM (2003) High number of diatom species in first-year ice from the Chukchi Sea. Polar Biol $26: 806-818$

Wassmann P, Slagstad D, Wexels Riser C, Reigstad M (2006) Modelling the ecosystem dynamics of the Barents Sea including the marginal ice zone II. Carbon flux and interannual variability. J Mar Syst 59:1-24

Welschmeyer NA (1985) Fluorometric analysis of chlorophyll $a$ in the presence of chlorophyll $b$ and pheopigments. Limnol and Oceanogr 39:1985-1992

Werner I (2000) Faecal pellet production by Arctic under-ice amphipods-transfer of organic matter through the ice/water interface. Hydrobiologia 426:86-96

Wexels Riser C, Wassmann P, Reigstad M, Seuthe L (2008) Vertical flux regulation by zooplankton in the northern Barents Sea during Arctic spring. Deep-Sea Res II 55:2308-2319

Witte U, Wenzhöfer F, Sommer S, Boetius A, Heinz P, Aberle N, Sand M, Cremer A, Abraham W-R, Jørgensen BB, Pfannkuche O (2003) In situ experimental evidence of the fate of a phytodetritus pulse at the abyssal sea floor. Nature 424:763-766 